traced a possible connexion with the St. Samson who is the patron saint of the nearby Goland Church. A menhir known as the Castle Dore stone, which once stood near the camp, is also thought to be connected with King Mark under the name Conomonus or Quonomorius, while a doubtful interpretation of a much obliterated commemorative inseription would point to Tristan being his son and not his nephew. Other suggestions, derived from like sources, have been put forward, of connexion with figures of Arthurian tradition. Although it is scarcely to be expected that excavation will bring to light anything in the nature of concrete evidence to support the connexion, the body of tradition which clings to this valley of Fowey encourages the hope that it preserves a folk-memory of what was once an important centre of early civilisation.

\section{International Cancer Congress}

THE second International Congress of the Scientific and Social Campaign against Cancer will be held in Brussels on September 20-26. The Congress is under the patronage of His Majesty the King of the Belgians and of Her Majesty Queen Elizabeth, and has the support of the Government. The National Executive Committee consists of Dr. Lerat (chairman), president of the Belgian National League against Cancer, Profs. Delrez, Dustin, Goormaghtigh and Maisin, directors of the Anti-Cancer Centres of Liège, Brussels, Ghent and Louvain respectively; Dr. Sluys, president of the Belgian Society for Radiology; Dr. Timbal, director-general of the Government Department of Hygiene; Mr. H. Marchal, treasurer, and Mr. W. Schraenen, general secretary of the Belgian National League against Cancer and of the Congress. The programme of the Congress has been divided into two main groups, embracing the scientific campaign and the social campaign against cancer, and the subjects on which official reports will be prepared and upon which individual communications are invited are grouped together under the following headings: (1) The experimental investigation of cancer, which comprises the study of carcinogenic substances, transmissible agents and viruses, growth substances, and factors of predisposition and resistance such as heredity, metabolism and immunity; (2) the diagnosis of cancer by histological, radiological and serological methods; (3) the treatment of eancer by surgical, medical and radiological methods. In the second group, on the social campaign against cancer, the subjects dealt with are : (1) Access of patients to diagnosis and treatment ; (2) medicosocial assistance to incurable cases ; (3) cancer and demography including statistics and racial incidence. The list of official rapporteurs is not yet complete, but among those who have agreed to present reports are: M. Borst, J. W. Cook, W. Cramer, H. F. Deelman, L. Dublin, A. P. Dustin, J. Ewing, W. E. Gye, H. Holthusen, E. L. Kennaway, J. Maisin, M. Nagayo, F. Pentimalli, Cl. Regaud, P. del Rio Hortega, G. Roussy, C. Rowntree, H. Schinz, F. Carter Wood. Further particulars may be obtained from Mr. W. Schraenen, General Secretary to the Congress, 13 rue de la Presse, Brussels, Belgium.

\section{Colonial Administration}

A symposium on "Peace and the Colonial Problem" published by the National Peace Council (39 Victoris Street, S.W.1. 6d.) contains the speeches delivered by Sir Arthur Salter, the Marquis of Lothian, Prof. N. Bentwich, Sir John Harris and others, at \& Conference organised by the National Peace Council and held at the Livingstone Hall, Westminster, in October 1935. Sir Arthur Salter states that he con. siders that it would be both wrong and impracticable at this moment to transfer colonies to the dissatisfied countries of the world. He holds, however, that a remedy might be found in an extension of the mandate principle, whereby colonies would be held under a double trusteeship (1) to the inhabitants of the country and (2) to the world in general. Countries holding mandates should be responsible for the execution of their trusteeship to an international authority under a mandate, and the terms of this mandate should be extended so as to remove so far as possible the economic disabilities suffered by countries not possessing colonies.

Prof. Norman Bentwich, in referring to the question of equality of economic opportunity, said that there should be real equality of opportunity for investment of capital and for obtaining concessions in the colonies. This would provide some alleviation of the economic grievances of those countries which are without colonies. $\mathrm{He}$ also advocated that the administrative services in colonies brought under mandate and in mandated territories should be open to the subjects of States other than the governing power. In Palestine it has been developed to some extent, and no difficulty has been found, for example, in working the medical or engineering services with persons coming from different countries. The adoption of a system of mandates and international responsibility would give an opportunity to foreign subjects and an assurance and a greater confidence to the native inhabitants of those countries.

\section{Rapid Growth of the Use of Electricity}

THE annual report of the Electricity Commissioners for the year ended March 31, 1935 (H.M. Stationery Office. $3 s$. ), records a noteworthy expansion of the public supply of electricity. There is an increase of 1,715 million units on the output of the previous year. This is the largest actual increase hitherto recorded, and is equivalent to a growth of $12 \cdot 1$ per cent. The expansion is largely due to the increase of the domestie load. The Commissioners point out that owing to the persistent demand for the facilities and amenities capable of being provided by a public supply of electricity, there will doubtless be a great increase in the present consumption before 'saturation point' will be reached. There will be a wide field of opportunity presented for the electrical and mechanical equipment of industry when the present factory generating plant and prime movers become obsolete. There are possibilities also attached to the further development of railway electrification. The steam. driven power stations included in the returns account 